International Journal of Social Science and Economic Research

ISSN: 2455-8834

Volume:05, Issue:12 "December 2020"

\title{
ANALYZING CHINA-UAE TRADE POTENTIAL UNDER THE CONTEXT OF THE BELT AND ROAD (B\&R) INITIATIVE
}

\author{
Mugeeb Mohamed Mohamed Al-Samhi ${ }^{1}$ and Muheeb Mohamed Mohamed Al-Samhi ${ }^{2}$ \\ ${ }^{1}$ College of Economics and Management, Nanjing University of Aeronautics and Astronautics, Nanjing \\ 210016, China \\ ${ }^{2}$ College of International Business, Shaanxi Normal University, Xi’an, China
}

DOI: 10.46609/IJSSER.2020.v05i12.005 URL: https://doi.org/10.46609/IJSSER.2020.v05i12.005

\begin{abstract}
The One Belt One Road (B\&R) initiative was started by China with the aim of developing a regional economic integration between Africa, Europe and Asia. The initiative has played a pivotal role in advancing China's economic interests in different parts of the world. The project seeks to promote enhanced regional collaboration with Africa, Europe, and Asia. China's key priority under the initiative include trade and investment cooperation with the aim of creating a conducive business setting in the three regions. The B\&R initiative has facilitated improved trade relations between China and the UAE. However, there is a paucity on studies exploring the impact of the initiative on the trade structure between the two nations. In this thesis the quantitative study sought to close this research gap by focusing on the impact of the project on the trade between China and UAE.

Gravity model analysis was used to determine the impact of the initiative and it emerged that there was a positive impact on the economies of both China and UAE as a result of increase GDP. The results show that China is UAE's main supplier, accounting for $8 \%$ of total imports. Additionally, the gravity model's R square had a value of 0.95 which implies that $95 \%$ of the variation in the data can be explained by the model. The model was also significant with a value of 0.035 . By the end of 2017, the trade volume between the two countries had reached a record of 53 billion dollars. Furthermore, the two nations have benefitted not only in terms of economic growth, but also in the fields of research, cultural activities, and education. The study suggests that China and UAE should continue holding talks on how to streamline their economic policies to open new markets and opportunities for investors from both sides. The B\&R project is expected to pool more resources from China's giant economy to UAE and eventually lead to economic growth. Additionally, there is need for UAE to tap on existing opportunities within the Chinese economy such as educational research, manufacturing, and textile. Future studies should
\end{abstract}




\section{International Journal of Social Science and Economic Research}

ISSN: $2455-8834$

Volume:05, Issue:12 "December 2020"

explore the impact of the B\&R initiative on specific economic sectors of China and the UAE. Researchers can also investigate the collaborative measures requires to minimize the trade imbalance between the two nations in order to strengthen the cooperation arising from the initiative. Additionally, researchers can explore the social and political impact of the B\&R initiative on the two partner countries.

Key Words: Gravity model; Belt and Road initiative; bilateral trade

\section{Introduction}

\subsection{Background}

The Belt and Road (B\&R) initiative was launched by the People's Republic of China in 2013 with the aim of establishing new cultural, commercial, political, and physical links across Eurasia. The initiative is set as a path for market prosperity, cultural integration and tolerance, global development, the integration of regional and international organizations, and peaceful and mutual cooperation [1]. The B\&R initiative places much emphasis on intercultural bonds, financial integration, trade promotion, connectivity, and policy coordination. Policy coordination means that the nations included in the project are supposed to actively engage in more international and regional cooperation [1]. Connectivity revolves around ports, natural gas and oil pipelines, telecommunication, air routes, highways, railways, and infrastructure facilities. To facilitate and promote trade and investment, the initiative is aimed at promoting regional economic integration as well as minimizing the investment costs, lower trade, and trade barriers.

The B\&R initiative encourages Chinese entrepreneurs and enterprises to go global and take advantage of the regional and international cooperation. With respect to intercultural bonds, the initiative aims at facilitating and promoting dialogues and exchanges between individuals from different ethnic and cultural backgrounds, heightening mutual friendship and understanding between partners as well as strengthening the friendly interaction between individuals from different nations across Eurasia [1,2]. This goal is set to be attained through several means. These means encompass recreational activities such as sports, and professional and academic interaction and exchanges between China and its strategic partners across the world. To this effect, the idea of $B \& R$ initiative is arguably an expression of the configuration and reinvention of the globalization phenomenon.

The $\mathrm{B} \& \mathrm{R}$ initiative is described as a road for peace. According to the principle, the $\mathrm{B} \& \mathrm{R}$ initiative can only be attained in a peaceful environment. The initiative was designed by China with the aim of supporting development across regions, promoting global governance, and enhancing the interconnected development in the form of multilateral trade, logistics networks, 


\section{International Journal of Social Science and Economic Research}

ISSN: 2455-8834

Volume:05, Issue:12 "December 2020"

climate change issues, sustainability in green development, investment in infrastructures, and foreign direct investment [2]

United Arabs Emirates has become one of China's trade partners due to B\&R initiative. The trade between UAE and China has improved continuously over the last few years. In 2015, the UAE's Minister of Foreign Affair, Al Nahyan, pointed out that the UAE is an important cultural, economic, and political hub between the East and the West as well as the gateway to the Middle East that thus, should seriously consider its relationship with China [3]. The UAE friendly business environment offers stable business hub for China to effectively expand its commercial interests. In the year 2000 the bilateral trade between China and UAE was under $\$ 2.5$ billion. The bilateral trade between the two nations has since then grown. In the year 2012 the trade reached $\$ 40$ billion. In addition, there has been increase of China presence within the UAE. There are over 4200 Chinese firms in the UAE with approximately 200,000 expatriates working and living there [3].

Specifically, the Minister asserted that China is a strategic partner and can play an integral role in bringing about development and stability in the UAE and even beyond. Following this observation by the minister, a broad range of bilateral agreements were signed across a wide array of sectors including clean energy, higher education, space cooperation, and energy.

The bilateral trade between the UAE and China has grown significantly, reaching $\$ 55$ billion in 2014 from $\$ 2.5$ billion in 2000 [3]. Additionally, the relationship between China and the UAE has been strengthened as a result of the UAE's role as a regional hub with a business-friendly environment, communication and transport, financial services, and infrastructure [4]. A significant number of Chinese companies are increasingly setting up regional offices in the United Arab Emirates with the aim of servicing contracts throughout the Middle East and Arabian Peninsula. In 2012, China's Premier Jiabao Wen, accompanied by Foreign Minister Jiechi Yang, made one of the most significant visits to UAE as part of a three-state overseas trip [3]. The Chinese delegation met with every senior member of United Arab Emirates' government, including Crown Prince Mohamed, Vice President Mohamed bin Rashid, and UAE's president Khalifa. During this important trip, UAE and China delivered a joint speech declaring that the two countries had established a strategic partnership. To this effect, UAE became the first Arab county within the Gulf region to establish a strategic partnership with China [3].

This historic partnership was based on 12 points. These 12 points include stronger cooperation and coordination in global organizations, cooperation in social development, sports, public health, tourism, education and culture, cooperation in military industry and trade, technical equipment and personnel training [3]. The other points encompass cooperation in intelligence 
International Journal of Social Science and Economic Research

ISSN: 2455-8834

Volume:05, Issue:12 "December 2020"

exchange, anti-terrorism, and law-enforcement security, bilateral cooperation in environmental protection, forestry, agriculture, taxations, and customs [3]. China and UAE also agreed to establish a comprehensive and a long-term strategic partnership in the energy sector, agreement to uphold the principle of non-interference in internal affairs and the principle of sovereignty as well as increased high-level political consultations and exchange of visits between the two countries.

\section{Problem Statement}

The B\&R initiative has arguably been termed as ambitious and a way for China to increase China-UAE relations and promote Sino-UAE cooperation on connectivity. A broad range of elements that make UAE an interesting regional for any kind of investment encompass its geopolitical location as a gateway to the European Union and Arab speaking countries, modern economy, good existing infrastructures, low wages, and political instability [4]. The trade between UAE and China will play an integral role in leveraging comparative edge to grow Chinese economy. The rapid expansion of UAE-China has increasingly become a key driver of China's Gross Domestic Product (GDP) growth. In 2015, China's trade grew by 3.5\% [5]. For China, UAE has increasingly become a growing market for its finished products, including mobile phones and other goods. The $B \& R$ initiative comes as an opportunity for China to increase the China-UAE global strategic partnership hence increasing cultural relations, investment and bilateral trade. United Arab Emirate is a great potential recipient of the B\&R initiative since it has welcomed Chinese investments in a broad range of fields, including transportation infrastructure, energy, and telecommunication [3]. However, there are no empirical studies that have explored the trade structure between the China and the UAE as well as the impact of the B\&R initiative on the trade between the two countries

\section{Purpose of the Study}

The quantitative study explored the trade structure between China and UAE and the impact of B\&R on China and UAE trade cooperation as well as the benefits associated with the initiative

\section{Research Questions}

The research questions guiding the study are indicated below:

i. What is the trade structure between China and UAE?

ii. What is the impact of B\&R initiative on trade structure between China and UAE?

\section{Research Methodology}




\section{International Journal of Social Science and Economic Research}

ISSN: $2455-8834$

Volume:05, Issue:12 "December 2020"

The study adopted a quantitative research design to investigate the trade cooperation between China and UAE within the context of B\&R initiative. Quantitative research uses numerical or statistical data to enumerate a research problem in an objective manner as well as show the causal relationship between variables. The study used secondary data derived from databases containing numerical trade data on China and the UAE. Specifically, the data used covered 2012 financial year to 2016 fiscal year. The study was founded on complementary and gravity model analysis of the trade between the two nations. The analysis was conducted using regression through Statistical Package for Social Sciences (SPSS).

\section{Organization of the Study}

The project is organized into five chapters. The first chapter presented the background of the study, the problem statement, the research questions, and the significance of the study. Chapter two of will cover literature review section. Specifically, the literature review section will evaluate peer-reviewed journal articles in an effort to review, analyze, critique, and enumerate works of other scholars regarding the trade structure between China and UAE, the effect of B\&R on China and UAE trade cooperation and the benefits associated with the initiative. The chapter also presents themed sections including B\&R Initiative, analysis of Chinese economy, ChinaUAE trade relations, infrastructure projects between China and UAE and summary of the literature review. Chapter three presents complementary analysis of the trade between China and UAE as well as the trade complementarity index analysis. Chapter four covers export trade potential from China and UAE. Specifically, the chapter covers the gravity model analysis and empirical analysis by regression model. The last chapter outlines the conclusions derived from the findings, recommendations for practice, and recommendations for further research.

\section{Literature Review}

The literature review chapter evaluates peer-reviewed journal articles in an effort to review, analyze, critique, and enumerate works of other scholars regarding the trade structure between China and UAE, the effect of B\&R on China and UAE trade cooperation as well as the benefits associated with the initiative. Specifically, this chapter explores a broad range of areas including B\&R initiative, China-UAE trade relations, and infrastructure projects between China and UAE.

\subsection{B\&R Initiative}

The $\mathrm{B} \& \mathrm{R}$ initiative is described as a road to peace. According to the principle, the $\mathrm{B} \& \mathrm{R}$ initiative can only be attained in a peaceful environment. The initiative was designed by China with the aim of supporting development across regions, promoting global governance, and enhancing interconnected development in the form of multilateral trade, logistics networks, climate change 


\section{International Journal of Social Science and Economic Research}

ISSN: $2455-8834$

Volume:05, Issue:12 "December 2020"

issues, sustainability in green development, investment in infrastructures, and foreign direct investment [2]. The Silk Road Economic and the 21st century Maritime Silk Road that are collectively termed as Belt and Road (B\&R) was initiated by the Chinese government in the year 2013. The concept has increasingly proved to play a pivotal role in socio-economic and political interests due to its impact on both maritime logistics and sea transport. The B\&R initiative is aimed at promoting the connectivity of European, Asian, and African contents to create and reinforce partnerships among the nations along the Belt and Road [7].

\subsection{China-UAE Trade Relations}

China-UAE trade relations have over the last few years increased exponentially and consistently through the era of interdependence, particularly since the People's Republic of China joined the World Trade Organization (WTO) and became one of the world's most assertive trade partners [3]. The trade between the UAE and China in the course of 1990s flourished because of a broad range of factors. Some of these factors include the UAE's oil reserves as well as China's perception of the UAE as the center of regional trade within the Gulf region. In 1993, China was a net energy importer and as such, it was attracted to the UAE's oil reserves. The bilateral trade between China and the UAE in 1990 accounted for more than $\$ 280$ million [3]. China has great ambitions to turn UAE among the international financial centers. UAE has considerably improved in terms of economic freedom. The economic restructuring can be linked to the strengthened business environment. Both China and UAE promotes each other's economic growth through exports as well as trade [10]. The two nations signed a partnership in the year 2012 meant to forge a friendly trade relationship. Approximately $60 \%$ of the China exports tends to pass through UAE and later re-exported to Africa and Europe. On the other hand, China accounts approximately $10 \%$ of UAE's non-oil products. UAE constitutes a significant market for the Chinese market. The bilateral trade between the two nations has considerably grown with the trade growing from $\$ 2.8$ billion in 2001 to $\$ 47.7$ billion in 2014 . The increased bilateral trade has been strengthened by closer financial ties [11].

Export from the UAE to China during this period was valued at \$41 million while export to UAE during the same period was valued at $\$ 246$ million [3]. By the end of 2000, the bilateral trade between China and UAE was just under $\$ 2.5$ billion. However, by the end of 2012, the bilateral trade between China and UAE was more than $\$ 42$ billion. China and the UAE have for the last years used their trade relationships to develop other facets of their relations including cultural, political, military, and energy ties. In the 1990s, the countries viewed energy as the future engine of trade relations between China and the UAE. However, energy was not central to bilateral trade between China and the UAE during this period [13]. In the same period, Chinese leaders increasingly realized the importance of diversifying global oil supply and the UAE saw China as 
International Journal of Social Science and Economic Research

ISSN: 2455-8834

Volume:05, Issue:12 "December 2020"

a long-term export with promising potential for future growth [3].

The relations between China and UAE are mainly built on trade. The UAE serves as a key hub for Chinese multinational corporations operating within the Middle East. In addition, Chinese banks have continued to capitalize on the promising potential offered by the UAE. A number of Chinese banks have been established across the UAE. For example, Industrial and Commercial Bank of China has established a branch in UAE. On the same note, the UAE has also been active across China's banking industry. Several branches have been established within mainland China. These included Union National Bank established in China back in the year 2007 and National Bank of Abu Dhabi (NBAD) that was established in the year 2012 in China [14]. Additionally, numerous key Chinese corporations outside the banking industry have started pursuing opportunities within the UAE. Approximately, 2,400 Chinese corporations are part of Dubai Chamber members. Majority of the Chinese firms sell machinery, garments, and electronics among others. As such, the UAE serves as a critical hub that facilitates Chinese expansion within the wider Middle East. Additionally, Chinese firms have begun to utilize Dubai International Financial Centre as connection to access markets within the region. Furthermore, the growing economic ties between China and UAE facilitate access to the untapped markets that are lucrative to both nations [14].

The two nations enjoy two-way trade with the trade having passed $\$ 35$ billion within the first nine (9) months of 2017. The two nations look forward to boost their overall trade links. Additionally, they have been able to build bilateral economic relations that has totaled to about $\$ 46.3$ billion in the year 2016. Chinese firms have continued to take part in the UAE's development operations as way of bilateral trade. In the year 2013, China came up with One Belt One Road Initiative as means of connecting different regions that are within the Belt and Road initiative. The UAE has for past participated in trade as well as investment operations across China [15]. Furthermore, within the Gulf Cooperation Council (GCC) states, the UAE has emerged as a critical partner to China. This has been attributed to UAE's overall improved prominence in terms of investment hub as well as regional trade hub. UAE is currently playing significant role towards internationalization of Chinese efforts. The two nations in their attempt to facilitate fruitful trade relations focus on three key themes including joint investment, currency cooperation as well as solar based green energy. Sometimes back China focused on renewing its renminbi swap agreement with the UAE as means of internationalization of Yuan. The two nations first signed their first bilateral currency swap pact in the year 2012. This is an indication that there are numerous avenues that the two nations have explored to promote their trade relations. Additionally, given the one belt initiative, UAE has the potential to become and remain among the key trade partners with China. Wealth, centrality and stability if UAE makes it a strategic hub for Chinese in terms of trade [16]. 


\section{International Journal of Social Science and Economic Research}

ISSN: $2455-8834$

Volume:05, Issue:12 "December 2020"

China is ranked as one of the largest UAE trade partners. China aims at realizing approximately $\$ 80$ billion within the next two years. UAE is strategically significant to China in terms of exports and imports as well as re-exports. UAE has adopted an open visa policy for China. Consequently, this has promoted trade and business between the two nations. The trade links between UAE and China are well-established facilitating long run trade relations. A number of UAE multinational corporations are exploiting a number of investment opportunities within China. With the historic $120^{\text {th }}$ Canton Fair the two states have been able to increase bilateral trade [17]. A series of bilateral diplomatic visits between UAE and China took place in back in the year 2015. The agenda of these diplomatic visits were to ensure continued advancement of the bilateral partnership that was established in 2012 under One Belt One Road or rather the New Silk Road Strategy. The strategy serves as means of connecting China with European, Asian, and African states. Additionally, trade volume between Chinese firms and Jafza has continued to increase rapidly. In the year 2002, the trade volume stood at $\$ 934.3$ million. In the year 2011, the trade volume reached $\$ 10.1$ billion. Subsequently, China is among Jafza's highest trade partners [18].

A number of Chinese cities including Beijing, Guangzhou, Kunming, Shanghai, Urumqi, and Hong Kong are directly connected to Dubai through direct flights. This demonstrates that China and UAE are conveniently connected. Such convenient connections between the two states tend to facilitate ideal business exchanges [19]. The growth in interactions between China and UAE have resulted to increased financial exchanges between financial institutions and banks. A rapid increase of bilateral trade between China and UAE has continued to thrive in the recent past. The overall value of the trade exchanges between UAE (Sharjah) and China in terms of imports, reexports, and exports increased by approximately $18 \%$ between 2010 and year 2012 . The bilateral trade between the two countries is likely to hit double figure under the New Silk Road initiative [19].

\subsection{Infrastructure Projects between China and UAE}

The People's Republic of China's role in infrastructure projects in the UAE is considerably smaller than the role it plays in Saudi Arabia. Nevertheless, the increased trade and political relationship between the UAE and China have promoted a greater for Chinese companies in the former. An agreement between ADNOC and CNPC was reached between China and UAE with the aim of enhancing cooperation in petrochemical and oil projects [3]. The UAE is increasingly becoming a significant market for China's project contracting industry. With a strong demand for the local construction market, the prosperous economy, and the skyrocketing oil costs, the People's Republic of China's project contracting business in the UAE has significantly developed over the last few years [4]. 
International Journal of Social Science and Economic Research

ISSN: 2455-8834

Volume:05, Issue:12 "December 2020"

\subsection{Summary of the Literature Review}

The study explored the trade structure between China and UAE and the effect of B\&R on China and UAE trade cooperation as well as the benefits associated with the initiative. The B\&R initiative was launched with the aim of encouraging Chinese entrepreneurs and enterprises to go global and take advantage of the regional and international cooperation [3]. Specifically, the $\mathrm{B} \& \mathrm{R}$ initiative comes as an opportunity for China to increase the China-UAE global strategic partnership hence increasing cultural relations, investment, and bilateral trade. The $B \& R$ initiative is further meant to provide a favorable business environment for nations in Europe, Asian, and Africa. It is also evident that the China-UAE trade relation has continued to grow stronger in the recent past. The bilateral trade between China and the UAE has experienced dramatic growth. Through the B\&R initiative, China has been able to build a constructive relationship with the UAE. The presence of expatriates living in the UAE has also increased through this initiative. Furthermore, China involvement in infrastructure projects in the UAE has increased through the initiative. However, there are no empirical studies investigating the trade structure between China and the UAE under the context of the B\&R initiative. As such, this study sought to close this research gap.

\section{Chapter 3 Trade Complementarily Analysis between China and UAE}

The Chinese economy has been expanding in the past few decades at a faster rate compared to the rest of the world. The rapid expansion has been attributed to increased technological innovation which has made the production of goods and services cheaper and affordable. As a result of this expansion, the People's Republic of China has chosen to explore the global and regional markets through economic integration and international relations. The $B \& R$ initiative is a good example of its strategy to strengthen economic, social, and political ties with the neighboring and regional blocks. With the introduction of the initiative, countries across the East and South Asia are set to benefit from low cost transport thus increasing economic integration and foreign trade. B\&R is set to offer cheaper transport costs for member countries as well as open new business opportunities across the Asian and Eastern African countries.

The initiative has not only benefitted the neighboring nations but has connected several countries to the mainstream market. Additionally, it has led to the economic empowerment of emerging economies. With UAE being among the first countries to formally accept China as a trading partner, the two countries have continued to enjoy a smooth business environment through trade and social cooperation. China being a big economy has its own gains and losses as a result of its investment in emerging economies such as the UAE. On the other hand, with a balanced trade, UAE could benefit more from the B\&R initiative since most of its economic potential remain untapped. The Chinese presence in the UAE economy means good for both partners as the 
International Journal of Social Science and Economic Research

ISSN: 2455-8834

Volume:05, Issue:12 "December 2020"

exchange of goods and service boost the economic growth between the two states. China has made major milestones in its economic growth and has some of the best technologies especially in the transport and infrastructure sector. As a result, countries such as the UAE which are trading with China are set to benefit from these technologies through trade. There has been an increasing presence of Chinese companies in UAE undertaking various economic projects. The primary aim of $B \& R$ initiative was to promote social, political, and economic development among the member states as well as enhance regional growth.

\subsection{UAE Foreign Trade Indicators}

Comparing the trades for the two countries helps in understanding the impact of the B\&R on the two states. Trade complementarily helps in assessing the extent to which the export profile of another state matches the import profile of another partner. A high trade complementarily index shows that the two states would eventually gain from increased trade and is useful in assessing the prospective bilateral and regional trade agreements. Past data indicates that China is UAE's leading importer. The United Arab Emirates has been ranked by the World Bank among the most dynamic markets in the world in relation to foreign trade. The country features in the list of the world's 16 top exporters and the world's 20 top importers of goods and services. As at 2017, trade accounted for $205 \%$ of its GDP. The country acts as a central business hub for Gulf countries, South Asia and East Africa. Even though its exports have been declining due to unstable oil prices, the country has maintained a steady flow in exports. The main products it exports to China are crude oil, dried fish, dates, and natural gas. On the other hand, UAE imports machinery, food stuffs, chemical products, and transport machinery.

Table 3.1 UAE foreign trade indicators

\begin{tabular}{llllll}
\hline Foreign Trade Indicators & $\mathbf{2 0 1 2}$ & $\mathbf{2 0 1 3}$ & $\mathbf{2 0 1 4}$ & $\mathbf{2 0 1 5}$ & $\mathbf{2 0 1 6}$ \\
\hline Imports of Goods (million USD) & 226,000 & 239,000 & 250,000 & 230,000 & 225,000 \\
Exports of Goods (million USD) & 349,000 & 379,000 & 375,000 & 265,000 & 265,900 \\
Imports of Services (million & 62,301 & 61,157 & 63,744 & 65,650 & 83,213 \\
USD) & & & & & \\
Exports of Services (million & 15,276 & 20,422 & 22,982 & 26,358 & 63,417 \\
USD) & & & & & \\
Imports of Goods and Services & 9 & 7.5 & 7.4 & -6 & 11.3 \\
(Annual \% Change) & & & & & \\
\hline
\end{tabular}


International Journal of Social Science and Economic Research

ISSN: 2455-8834

Volume:05, Issue:12 "December 2020"

\begin{tabular}{lccccc}
\hline $\begin{array}{l}\text { Exports of Goods and Services } \\
\text { (Annual \% Change) }\end{array}$ & 17.5 & 6.1 & 1.8 & 5.2 & 6.5 \\
$\begin{array}{l}\text { Imports of Goods and Services } \\
\text { (in \% of GDP) }\end{array}$ & 85.3 & 85.2 & 89 & 96 & 101.4 \\
$\begin{array}{l}\text { Exports of Goods and Services } \\
\text { (in \% of GDP) }\end{array}$ & 100.3 & 100.5 & 99.1 & 100.4 & 103.8 \\
\begin{tabular}{l} 
Foreign Trade (in \% of GDP) \\
\hline
\end{tabular} & 185.6 & 185.8 & 188.1 & 196.4 & 205.3 \\
\hline
\end{tabular}

Source: World Trade Organization; World Bank

Table 3.2 UAE main suppliers

\begin{tabular}{l|l}
\hline Main Suppliers & $\mathbf{2 0 1 6}$ \\
\cline { 1 - 2 } (\% of Imports) & \\
\hline China & $8.30 \%$ \\
United States & $7.60 \%$ \\
India & $6.90 \%$ \\
Germany & $4.60 \%$ \\
Japan & $3.60 \%$ \\
\hline
\end{tabular}

Source: WTO, World Bank

\subsection{China's Foreign Trade Indicators}

China, basing on its giant economy has a significant impact on the global markets. It's one of the leading exporters in the entire market. Table 3.3 shows the foreign trade volume of China which has been increased over time. Also, table 3.4 shows China's main suppliers, those states which export their goods to China.

Table 3.3 China's foreign trade indicators

\begin{tabular}{lrrrrr}
\hline Foreign Trade Indicators & $\mathbf{2 0 1 2}$ & $\mathbf{2 0 1 3}$ & $\mathbf{2 0 1 4}$ & $\mathbf{2 0 1 5}$ & $\mathbf{2 0 1 6}$ \\
\hline Imports of Goods (million & $1,818,405$ & $1,949,990$ & $1,959,233$ & $1,681,951$ & $1,587,431$ \\
USD) & & & & & \\
Exports of Goods (million & $2,048,714$ & $2,209,005$ & $2,342,293$ & $2,274,949$ & $2,098,161$
\end{tabular}


International Journal of Social Science and Economic Research

ISSN: 2455-8834

Volume:05, Issue:12 "December 2020"

\section{USD)}

Imports of Services (million USD)

280,260

329,419

450,805

466,330

453,014

Exports of Services (million

USD)

$200,586 \quad 205,778 \quad 279,423 \quad 285,476 \quad 208,488$

Imports of Goods and Services

(in \% of GDP)

$\begin{array}{lllll}22.7 & 22.1 & 21.6 & 18.5 & 17.4\end{array}$

Exports of Goods and Services

(in \% of GDP)

25.4

24.5

24.1

22

19.6

Trade Balance (million USD)

Foreign Trade (in \% of GDP)

311,570

358,981

435,042

576,191

494,077

$48.1 \quad 46.6$

45.7

40.5

37.1

Source: WTO

Table 3.4 China's main suppliers

\begin{tabular}{l|r}
\hline Main Suppliers & $\mathbf{2 0 1 6}$ \\
\cline { 1 - 1 } (\% of Imports) & \\
\hline South Korea & $10.00 \%$ \\
Japan & $9.20 \%$ \\
United States & $8.50 \%$ \\
Germany & $5.40 \%$ \\
Australia & $4.50 \%$ \\
\hline
\end{tabular}

Source: WTO

From the late tables, China remains the main supplier of products to United Arab Emirates, indicating the increased economic relations between the two countries since 2012 before the B\&R project was launched. China leads at $8 \%$ followed by the United states. However, the UAE does not feature in the list of top China's suppliers. This is not an indication that China does not import from UAE, however, the amount of imports from UAE are lower compared to other countries which export to China such as South Korea and Japan. Additionally, the data above shows that China has a big economy as shown in the volume of exports to the global market and 
International Journal of Social Science and Economic Research

ISSN: 2455-8834

Volume:05, Issue:12 "December 2020"

the imports from the world. Even though its exports have been increasing significantly, the imports continue to shrink every year thus indicating the country is finding alternative goods and services locally as opposed to expensive imports from other foreign countries.

\subsection{Foreign Trade between the UAE and China}

UAE has been increasing its imports, however, the exports have been declining over time and this could be attributed to the unstable oil prices in the Asian and Middle East countries. In the past decade, the oil and natural gas sector has been experiencing turbulent times as global prices continue to drop. Countries whose economies heavily depend on oil and natural gas have been worst hit by the global prices which have been dropping all through. Moreover, the foreign trade as a percentage of the country's GDP shows that UAE has been increasing its foreign trade since 2012 rising to $205.3 \%$ in 2016 which is a good show of economic growth. On the other hand, China has been on the downward trend. The foreign trade as a percentage of the country's GDP declined from $48.1 \%$ in 2012 to $37.1 \%$ in 2016 , a decline of $11 \%$. As explained earlier, the shrinkage is caused by the country's decision to continuously cut its imports.

Table 3.5 Volume of foreign trade between the UAE and China

The volume of foreign trade between UAE and China in million dollars

\begin{tabular}{lrrrrrr}
\hline \multicolumn{7}{c}{ Total non-oil trade } \\
\hline Year & 2012 & 2013 & 2014 & 2015 & 2016 & 2017 \\
Exports & 2184 & 1996 & 2879 & 3001 & 4216 & 5025 \\
Imports & 31893 & 36390 & 44997 & 44530 & 42114 & 48305 \\
\hline \multicolumn{7}{c}{ Direct Trade } \\
\hline
\end{tabular}

Free Zone Trade

\begin{tabular}{lrrrrrr}
\hline Year & 2012 & 2013 & 2014 & 2015 & 2016 & 2017 \\
Exports & 228 & 229 & 403 & 487 & 553 & 1057 \\
Imports & 15950 & 18922 & 22850 & 21688 & 19693 & 26587 \\
\hline
\end{tabular}

Balance of trade

\begin{tabular}{lllllll}
\hline Year & 2012 & 2013 & 2014 & 2015 & 2016 & 2017 \\
\hline \hline
\end{tabular}


International Journal of Social Science and Economic Research

ISSN: 2455-8834

Volume:05, Issue:12 "December 2020"

\begin{tabular}{lrrrrrrr}
\hline \multirow{2}{*}{ balance of trade } & \multicolumn{2}{c}{-29709} & -34394 & -42118 & 41530 & 37898 & 43280 \\
\hline Year & foreign trade growth & & & & \\
percentage growth & 2012 & 2013 & 2014 & 2015 & 2016 & 2017 \\
& & 13 & 25 & -1 & -3 & 15 \\
\hline
\end{tabular}

Figure 3.1 Total non-oil trade between UAE and China

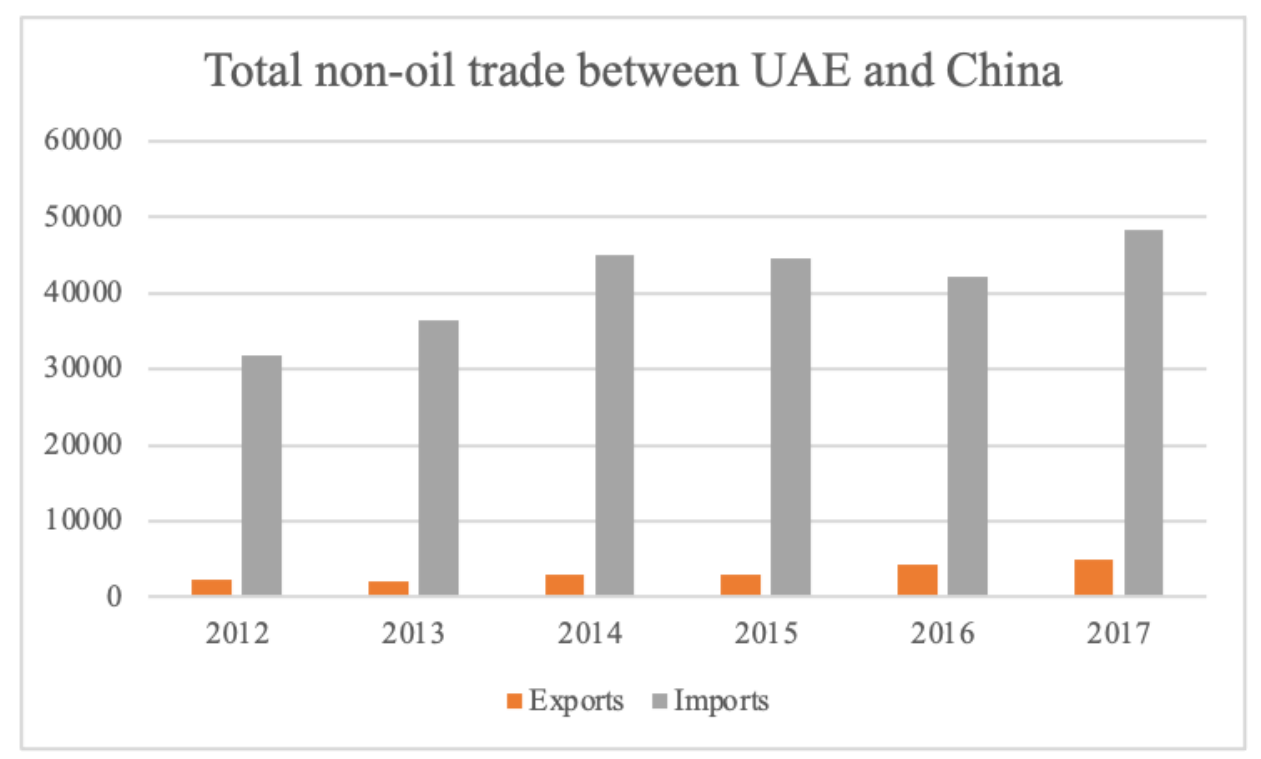

From the above figure 3.2, it is evident that UAE imports a huge volume of goods from China than its exports to China. Even though there has been an increase in its imports from China, there was a slight drop in 2015 and 2016 before recording the highest volume of non-oil goods in 2017. At the same time, UAE's exports to China have been increasing steadily since 2012 recording the highest volume in 2017. The mutual dependence between the two countries has made it easier for the exchange of goods and services including labor. UAE finds China as the most preffered trading partner and the country has gained enormouslly from the giant economy through infrastructural and technological projects. 
International Journal of Social Science and Economic Research

ISSN: 2455-8834

Volume:05, Issue:12 "December 2020"

Figure 2.3 Direct trade between UAE and China

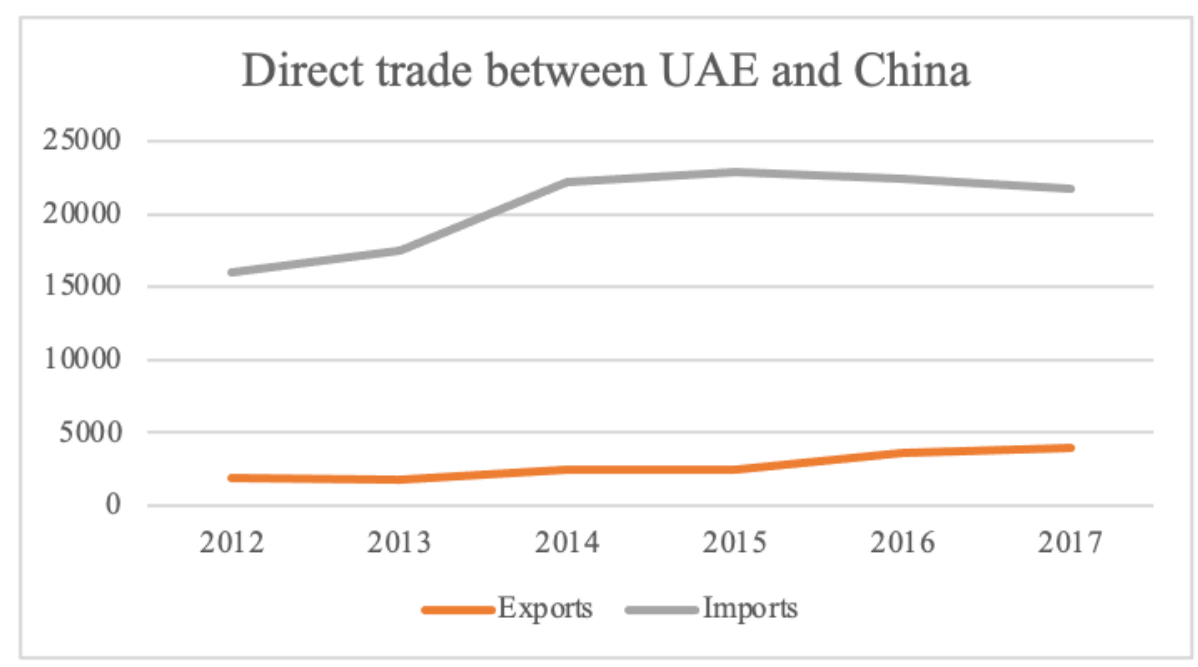

Direct trade between the UAE and China also varies in terms of exports and imports. As in figure 3.3 for the exports, the direct trade between UAE and China has been on the rise. This implies a positive impact for UAE since it is investing more in the Chinese economy whose potential is greater than that of UAE. UAE's economy is projected to improve because of more exports to China through direct trade. However, the direct trade for imports increased since 2012 until 2016 when it started declining. The implication of this decline is a gain on the side of UAE through the reduction of trade balance while it has a negative impact on the Chinese economy since less exports reduces the country's GDP thus affecting its economic growth. However, the impact on the Chinese economy could be insignificant since UAE is not its main consumer.

Figure 3.3 Free zone trade between UAE and China

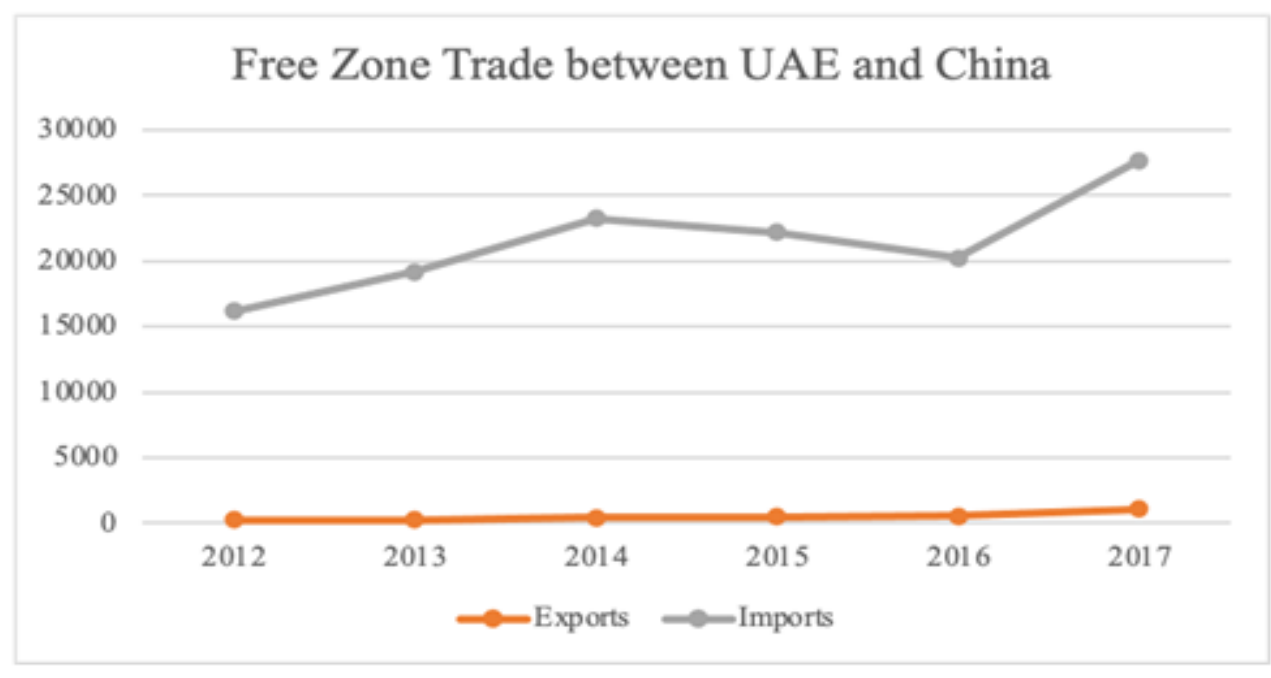


In the above figure 3.4 the free zone trade between the two countries shows an upward trend where both the exports and imports are on the rise. However, the imports between 2015 and 2016 declined then later picked in 2017.

Figure 3.4 Percentage Growth

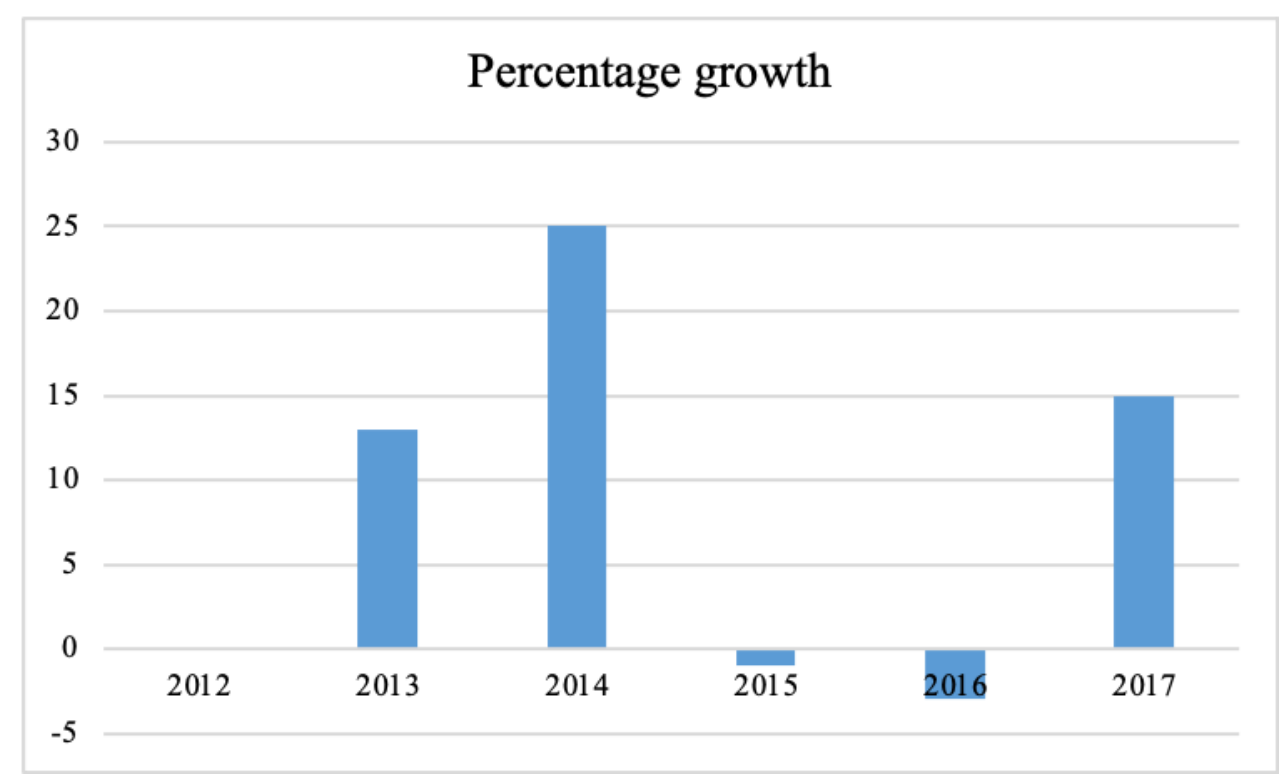

Figure 3.5 shows that the two countries experienced the highest growth rate in 2014 standing at $25 \%$. However, this was followed by a slump in the growth in 2015 and 2016, which both recorded negative foreign trade growth. From the above analysis. it is evident that since the $B \& R$ initiative was officially launched, the two countires have been engaging in ecocnomic relations through trade. The two states have been mutually benefitting from each other through the exchange of goods and services. Whereas China has been depending heavily on crude oil and natural gas from UAE, it has found a good market in UAE for its machinery, technology products, and transport infrastructure. Even though there was a decline in the imports in UAE between 2015 and 2016, the effect was not severe to both economies. It is evident that B\&R initiative has been part of the success in foreign trade between the two states thus impacting positively on their economic growth rate. Even though there is a huge gap between the exports and imports in the two states, the gap can be associated to the sizes of their individual economies. China is ranked as one of the top five leading economies in the world and this expalins the huge volume of trade it exports to UAE. B\&R initiative has, therefore, opened new markets for the two states through cheap transport systems and reduced tariffs on imports. The good economic relations between the two countries have been very critical in enhancing social, economic, and political integration between China and UAE. 


\section{International Journal of Social Science and Economic Research}

ISSN: $2455-8834$

Volume:05, Issue:12 "December 2020"

The above complementarity analysis shows that both countries are benefitting economically from their bilateral trade. The foreign trade growth reveals an increased business activity between China and UAE which has a positive impact on both economies. First, UAE benefits from technology and machinery from China. The infrastructural tecnhology has enabled UAE to expand its economy through the devlopment of new transport networks. Furthermore, the presence of Chinese companies in UAE, which act as a central hub to the Asian countries places the state at the central role acting as a regional hub. China also benefits from the crude oil and natural gas which is UAE's major export commodity. Besides, UAE has offered China a better place to export its products as a result of the commissioning of the B\&R project which now links the two countries directly. For an increased economic gain, both countries should continue opening up new potential markets for their partners and allow investments to boost economic growth. Additionally, China should increase its imports from UAE to ensure that there is a high complimentarity. Moreover, the two states should jointly come up with policies to allow smooth runnning of businesses and provide an enabling environment for investment. Such policies include tax exepmtions and reduction of tarrifs on both imports and exports to boost business activity.

\section{Chapter 4 Export trade potential from China to UAE}

\subsection{Data}

The study utilized secondary data derived from databases containing quantitative trade data on China and the UAE. Specifically, the researcher utilized data from 2012 to 2016 financial years. The data was retrieved from World Trade Organization database.

\subsection{The Gravity Model Analysis}

The gravity model analysis is becoming common as a result of its near accuracy in predicting bilateral trade flows. The model is the best in analyzing the intra-regional trade. Even though it has number of advantages, it fails to account for the possible effect of terms of trade related to trade creation. In this manner, the simulated results arising from the gravity model are often upwardly biased. Another problem is the fact that the model provides estimates of the results in a static framework as opposed to a dynamic framework whose projections and estimates take into account other factors such as technological spill-over, the terms of trade, the scales of economies, and the trade liberation. The effect of these factors is that they reinforce the short-term trade thus reducing the estimations of the long-run impact. The model considers the country's Gross Domestic Product and the Per Capita Gross National Product in its estimations to estimate the impact of the trade. 
International Journal of Social Science and Economic Research

ISSN: 2455-8834

Volume:05, Issue:12 "December 2020"

In this analysis, the gravity model analysis is used to assess the nature of trade relations between China and the United Arab Emirates. In this case, the test is to check the impact of the B\&R project between the two countries to ascertain whether trade has improved between China and UAE after the commissioning of the B\&R initiative in 2013. The assessment through the gravity model will focus on the GDP of the two countries and the volume of bilateral trade from 2013 to 2017 to ascertain the underlying effect of the project. As discussed earlier, UAE had signed a deal to trade with China, thus opening the markets to their partners. It is, therefore, imperative to assess the progress of the deal under the $B \& R$ initiative which was majorly tailored to increase economic and social integration between China and UAE. In the model, it becomes important to focus on the distance between the two states as one of the variables which could impact on the bilateral trade.

Table 4.6 Bilateral trade between UAE and China

\begin{tabular}{lcrrr}
\hline & $\begin{array}{l}\text { Trade volume } \\
\text { (In Million }\end{array}$ & GDP for & \multicolumn{2}{l}{ GDP for China } \\
Year & US \$) & UAE (i) & (j) & Distance \\
\hline 2012 & 34078 & 374 & 85605 & 4998 \\
2013 & 38386 & 390 & 96070 & 4998 \\
2014 & 47876 & 403 & 10482 & 4998 \\
2015 & 47530 & 357 & 11064 & 4998 \\
2016 & 46330 & 348 & 11199 & 4998 \\
2017 & 53329 & 390 & 12300 & 4998 \\
\hline
\end{tabular}

Table 6 shows the bilateral trade between the two states, and it is evident that the trade volume has been increasing significantly from 34,078 million dollars to the current 53,329 million dollars. These comprise of both the exports and imports exchange between the two states. The increasing trade volume indicates the positive impact of economic relations between the two states. However, it is imperative to note that even with the huge trade volume, China still command a greater percentage (over $85 \%$ ) of the total trade volume in form of exports to UAE. This has been attributed to the fact that China's economy is significantly large compared to that of UAE. Even with this greater control of the trade volume, data also indicates that UAE has been increasing its exports to China over the past years in a bid to bring a balance in the bilateral trade. 
International Journal of Social Science and Economic Research

ISSN: 2455-8834

Volume:05, Issue:12 "December 2020"

Arguably, the GDP for UAE for the past five years has not been steady. The unstable oil prices have been part of the problem since crude oil and natural gas account for over $80 \%$ of UAE exports. With unstable oil prices, UAE is likely to gain less from the bilateral trades as it will be forced to import products from China at higher prices without any export to supplement the deficit created by the imports. The result of increasing oil instability would be reduced GPD which eventually impacts negatively on the bilateral trade between the two states. China is a fastgrowing economy globally. This is evident from its GDP for the last five years. The country has focused mainly on foreign investment as it seeks to become one of the leading global economies. China specializes in transport and infrastructure development and foreign investments across the world. As a result, its domestic product has improved and is projected to hit 13 billion dollars by the end of 2018. UAE stands to benefit from the giant economy through grants, trade agreements, reduced tariffs, and increased direct foreign investments. Currently, China has direct foreign investments in UAE amounting to 2, 233 million dollars while UAE has the same in China amounting to 39.3 million dollars and this is expected to increase as a result of enhanced trade policies between China and UAE.

The gravity model is given by the following formula:

$\log (\mathrm{Xij})=\mathrm{a}+\beta \log (\mathrm{GDPi} * \mathrm{GDPj})-\beta \log ($ Distance $)$

In this case, $\mathrm{Xij}=$ the trade volume between the two countries (China and UAE) GDPi is the Gross domestic product for UAE while GDPj represents China Taking the logarithm of the values, the table below is obtained.

Table 4.7 Gravity model analysis of trade between UAE and China

\begin{tabular}{lrrr}
\hline Xij & \multicolumn{2}{c}{ GDPi } & \multicolumn{2}{c}{ GDPj } & \multicolumn{2}{c}{ Distij } \\
\hline 4.5325 & 2.5729 & 6.9325 & 3.6988 \\
4.5845 & 2.5911 & 6.9826 & 3.6988 \\
4.6801 & 2.6053 & 7.0204 & 3.6988 \\
4.6770 & 2.5527 & 7.0439 & 3.6988 \\
4.6659 & 2.5416 & 7.0492 & 3.6988 \\
4.7270 & 2.5911 & 7.0899 & 3.6988
\end{tabular}

From the above table, we ran the gravity model to obtain the equation

\subsection{Empirical Analysis by Regression Model}


International Journal of Social Science and Economic Research

ISSN: 2455-8834

Volume:05, Issue:12 "December 2020"

This section presents a regression analysis to establish whether the data best fits the model. The analysis also helps to predict the level of trade between China and the UAE after the adoption of the $\mathrm{B} \& \mathrm{R}$ initiative.

Table 4.8 Regression analysis

\begin{tabular}{lr}
\hline \multicolumn{1}{c|}{$\begin{array}{c}\text { Regression } \\
\text { Statistics }\end{array}$} & \\
\hline Multiple R & 0.9777 \\
R Square & 0.9559 \\
Adjusted R & \\
Square & 0.8898 \\
Standard Error & 0.0238 \\
Observations & 6 \\
\hline
\end{tabular}

The regression diagnostics above indicate that the current gravity model can explain $95.59 \%$ of the variation in the data provided. This indicates the data best fits the model thus making it the best predictor of the level of trade between China and UAE after the introduction of B\&R initiative. Furthermore, if the model is subjected to another data of the same nature, it has the potential of explaining $88.98 \%$ of the variation.

Table 4.9 ANOVA table

\begin{tabular}{lccccc}
\hline ANOVA & & & & & \\
\hline & & & & & Significance \\
& $d f$ & $S S$ & $M S$ & $F$ & $F$ \\
\hline Regression & 3 & 0.0246 & 0.0082 & 14.464 & 0.0355 \\
Residual & 2 & 0.0011 & 0.0006 & & \\
\hline Total & 5 & 0.0258 & & & \\
\hline
\end{tabular}

Table 4.10 Regression coefficients

\begin{tabular}{lllll} 
& Coefficients & Standard Error $\quad$ t Stat & P-value \\
\cline { 2 - 3 } & Copyright C IJSSER 2020, All rights reserved & Page 3778
\end{tabular}


International Journal of Social Science and Economic Research

ISSN: 2455-8834

Volume:05, Issue:12 "December 2020"

\begin{tabular}{lcccc}
\hline Intercept & -5.3336 & 1.8560 & -2.8737 & 0.1028 \\
GDPi & 0.4050 & 0.4342 & 0.9327 & 0.4494 \\
GDPj & 1.2729 & 0.1935 & 6.5781 & 0.0223 \\
\hline Distij & -0.81 & 0.05 & -17.28 & 0.00176 \\
\hline
\end{tabular}

The regressions coefficients are critical in developing the gravity model for the data. In this case, the independent variable is the bilateral trade between UAE and China. The independent variables are the GDPs for the two countries and the distance. From the coefficients, the model is developed as follows.

Bilateral trade $(\mathrm{ij})=-5.3336+0.4050 \mathrm{GDPi}+1.2728 \mathrm{GDPj}-0.81 \mathrm{Distij}$

The model shows that the GDP for both states has a significant impact on the bilateral trade. An increase in one unit in GDP for UAE would translate to an increase in bilateral trade by 0.405 . Similarly, an increase in China's GDP by one unit would result in an increase in bilateral trade between the two states by 1.2728. Comparing the two GDPs, it implies that China's economy has a higher impact on the bilateral trade than UAE's GDP. Additionally, the distance has a negative impact on the trade between the two states. An increase in distance by one unit would significantly result in a drop in trade by 0.81 . However, the distance will vary and greater measures need to be taken taking into account the distance between the producer and the consumer of the products between the two states.

From the ANOVA table, the model is significant in predicting the nature of bilateral trade. The significance value of 0.035 , which is less than the conventional 0.05 indicates that the $B \& R$ initiative has played a key role in enhancing trade between China and UAE. Regarding the significance of the variables, it is only the distance and China's GDP that have a major impact on the bilateral trade. The assumption is that the UAE's small economy might not have a major impact to the giant economy and thus it is not highly significant.

\subsection{Summary}

As a result of the global trend, countries have continuously shifted from regional trade strategy to sub-regional and even bilateral trade agreements. The increasing bilateral trade agreements have resulted in speedy economic growth of involved partners. The above analysis on the case of China and UAE has been majorly attributed to the $B \& R$ initiative which was launched by China in 2013. The B\&R project whose primary aim was to increase economic and social integration among the member states has taken effect in most of the countries making it easier for the 


\section{International Journal of Social Science and Economic Research}

ISSN: $2455-8834$

Volume:05, Issue:12 "December 2020"

movement of goods and services. Moreover, the project has reduced the cost of transportation across Asia. The road and belt project has opened up new markets through policy formulation and free trade agreements to remove trade barriers. China is seen as being ahead as a result of its economic liberation initiated since 1978, and any state which partners with China is deemed to benefit from its expansive economy. For effective bilateral trade, China and UAE have started negotiations for a free trade area to allow easy movement of goods and services between the two states. China has even made UAE the central hub for most of the Arab countries as it continues negotiating more bilateral ties under the B\&R initiative [4].

The bilateral ties between China and UAE can increase development and generate both social and economic benefits especially to a growing economy such as UAE. From the analysis, it is evident that $\mathrm{B} \& \mathrm{R}$ project has been instrumental in bringing the two countries together even in other activities such as sports. The bilateral relations go a long way in developing long-lasting ties between the two states. China in the recent past has increased its activities in the global market with its high penetration being witnessed across African countries. China is investing more in infrastructure such as railways, roads, and power generation across Africa which could see it rise to the top of the global economy. Currently, China is the second largest global economy while UAE is the second largest economy in the Arab economy and their bilateral ties would eventually result in a greater economic progress. A number of Chinese companies are taking part in UAE's development activities and this implies a high trade volume between the two states. Some of the projects include the Khalifa Port Terminal project which was awarded to China's Cosco company. There exist several opportunities in the UAE market compared to the Chinese economy. The annual investment meeting has been identified as the gateway for the two countries to identify and exploit business opportunities. The sixth joint economic committee session held in Beijing in September 2017 saw the two countries agree to cooperate in 13 vital sectors of their economies. The sectors include trade and economic ties, renewable energy, SMEs and innovation, health, education, tourism, infrastructure, investment, financial services, aviation, standards, and local cooperation. The two states have agreed to continuously cooperate in the formulation of business policies to allow investors from both partner states to exploit available opportunities in their markets.

The growth of partnerships between China and the UAE is evident in the above analysis as their GDPs have increased significantly over time. The investment currently underway in UAE being championed by the Chinese government and the private investors from China is expected to improve UAE economic global rating. Being the second largest economy in the Arab business environment, the country is better placed in terms of economic and social integration. Serving as a central place for Chinese penetration to other Arab economies, UAE will not only benefit from China's presence in its economy, but also the rest of the Arab states which export their products 


\section{International Journal of Social Science and Economic Research}

ISSN: $2455-8834$

Volume:05, Issue:12 "December 2020"

to UAE. The increased presence of China in UAE is likely to pool other resources from the neighboring countries such as talents which in turn improve the host economy. The choice of UAE as China's preferred trading partner in the Arab world is due to its political stability that has provided an enabling environment for both local and foreign investors.

For the last three years, China has been the top trading partner of UAE with the total imports from China amounting to $8 \%$ of UAE's world imports. With the trend being witnessed between the two states, UAE is the greatest beneficiary because of numerous opportunities existing in its economy. Even though the impact might not be evident in the short-run, the long run impact is a rapid economic growth. Another factor which has improved the bilateral trade is the fact that every state depends on the products of one another. China has not invested heavily in petroleum exploration unlike UAE whose crude oil is the major export. On the other hand, UAE has not developed a highly sophisticated infrastructural technology like China. The gap created by these deficiencies make the two-state dependent on each other. This has laid the foundation of talks on free trade agreements to boost their exports. There has been an increasing impact of Chinese economy on UAE and this is evident from the gravity model developed. An increase in the economic growth of China translates to increased investment in UAE as more funds are made available and channeled to new projects in the country. The increasing China's economy means well for it partners as it finds more funds to lend to developing countries to fast-track their development projects.

\section{Chapter 5 Conclusions and Recommendations}

\subsection{Conclusions}

The above analysis has revealed the extent to which UAE and China have both benefitted from the B\&R initiative. It is evident that the success of any bilateral ties depends upon the goodwill from partner and their economic and political stability. It is extremely difficult to transact business in an unstable economy riddled with corruption, poor economic policies, and poor governance. Additionally, a peaceful nation provides a good business environment for the foreign investors and local SMEs to invest. The UAE has managed to stabilize its economy, coming second in the entire Arab region, as a result, it has attracted business from China, which is currently its top partner. The analysis indicates that the two states have been strengthening their bilateral ties since 2012 after UAE agreed to partner with China in a number of development projects. The $\mathrm{B} \& \mathrm{R}$ project has come to cement the relationship between China and UAE resulting in increased business transactions between the two states. Even though the economies are not at par, UAE has chosen to follow the footsteps of China, awarding numerous major projects to Chinese firms to boost their relationship and also gain from their expertise particularly in the infrastructure sector. Moreover, China has not overlooked UAE's small 
International Journal of Social Science and Economic Research

ISSN: 2455-8834

Volume:05, Issue:12 "December 2020"

economy, but has allowed UAE to set up business in China and even imported labor from UAE.

The strategic location of UAE in the Arab region has impacted positively on its suitability to act as the central hub for which China can penetrate to the rest of the Arab countries. The presence of global Chinese companies has created new job opportunities for the UAE citizens thus boosting the national income levels. The analysis has also shown that China's economy has a major impact on the UAE's business environment. An improvement in the Chinese GDP translates to the allocation of more resources to the development projects being undertaken in UAE. Some of the projects include infrastructural development and technology. The impact of Chinese imports which are mainly transport and technology goods continue to enhance technological levels and communication networks across UAE.

\subsection{Recommendations}

There exists untapped potential in both countries especially in UAE since it is one of the fastest growing economies in Arab. UAE is an expanding economy and there is need for new technologies to expand its infrastructure and communication networks. On the other hand, China still depends heavily on crude oil products and thus this is an existing business opportunity for UAE. The two countries can benefit from each other by ensuring there is balance of trade in their bilateral agreements and enhance policies which support mutual benefit. China needs to lower the tariffs it imposes on its imports to open more opportunities for goods and services from UAE. The study as well as past literature indicates that the trade between the two nations is unbalanced in favor of China. The trade imbalance dates back to the 1990s where Chinese exports to the UAE were valued at $\$ 1$ billion against $\$ 85$ million worth of UAE's exports to China [19]. As such, creating more opportunities for UAE to export more of its products would aid in ensuring that the two countries narrow the trade balance gap.

Furthermore, UAE should invest more in the existing ties with its partner to promote economic integration and business growth. To facilitate the process, UAE must remove all the trading policies that hinder direct foreign investment and open the local markets to investors from its partner. The B\&R project is the primary initiative that puts the two countries together and each state must devise ways to tap the opportunities brought by the belt and road program such as importing goods at a cheaper cost from the partner state. China can use the project to access new markets and create more customers for its huge production industry. UAE can benefit by transporting crude oil to China through road and rail which is way cheaper and safer than other transportation methods such as through the sea which often possess environmental risks as a result of oil spillage.

$\mathrm{UAE}$ can benefit from the $\mathrm{B} \& \mathrm{R}$ project and its strong relationship with China by enhancing 


\section{International Journal of Social Science and Economic Research}

ISSN: $2455-8834$

Volume:05, Issue:12 "December 2020"

skills and expertise necessary to develop new industries and reduce overdependence on limited number of economic sectors. The states can engage in exchange program where specialists from UAE can visit China and learn new ways of performing different activities and bring back the skills to develop their own economy. On the other hand, China has an opportunity of learning more regarding the crude oil sector. Through this exchange program, skills are shared and distributed across all the sectors of the economy and in the long run, business growth is enhanced. The states can also tap the opportunity in the aviation sector which currently has a maximum of 75 flights per week between UAE and major Chinese cities. This is an opportunity to enhance the air transport sector and the states may engage in talks on how best they can promote their own airlines without creating stiff competition in the markets. Such things could involve reducing charges for the airlines at the airports and having special reservations for their business partner. Additionally, the two countries can make the visas available for the citizens of the two states to ease movement. Data shows that about 60 percent of China's export passes through UAE before being re-exported to Africa and Europe and this explains the importance of UAE to China's economy. The states need to keep evaluating their bilateral trade policies to adjust to the global business dynamics and identify new opportunities in their partner's economy.

China and the UAE could also invest in their own security by having joint training sessions and improvement of military equipment to keep the countries safe from any external pressure. Global terrorism is on the rise and they should work closely on safeguarding and securing the B\&R initiative. Such measures involve joint research on the latest security technology that can help in averting major losses experienced in the past as a result of terrorism. The fact that about 60 percent of China's exports pass through UAE calls for increased surveillance at the airports and railway networks to safeguard the products from any danger. UAE needs to open up more opportunities for the Chinese firms in the manufacturing, construction, and textile industries to boost its exports. In 2017, Dubai Multi Commodities Centre, the largest industry free zone in UAE signed a Memorandum of Understanding with X'ian International Trade and logistics Park in Shanxi Province. The primary objective of the MoU was to open new opportunities in the UAE and China with the view of expanding the markets as well as coming up with joint trade missions and economic delegations. As a result of the MoU, many Chinese firms in UAE have begun expanding their business and opening new branches.

Moreover, there are opportunities in the field of education and the two states can invest in research and innovation. In 2017, UAE university signed another MoU with Zhejiang University of China with the aim of promoting scientific research. Innovation centers will enhance the exchange of talents and bring in new expertise from partner countries. UAE needs to diversify its economy to reduce its over-reliance on imports from China since it impacts negatively on its GDP. Setting up new industries will help in developing other sectors which are currently 


\section{International Journal of Social Science and Economic Research}

ISSN: $2455-8834$

Volume:05, Issue:12 "December 2020"

contributing a smaller percentage to the country's exports. The presence of Arab-China Technology Transfer Company should be an incubation center to develop the right skills to set up new businesses in the sectors dominated by the partner states. The company focuses on technology transfer between China and Arab region and UAE should be the first beneficiary since is the China's preferred center for global trade in the Arab economy. B\&R project has proved to be the best tool to bring the Arab nations closer to China and enhance their regional and bilateral relations. Its completion will see more countries get connected to China, the world's second largest economy and its impacts will be felt through development projects. China has been funding several infrastructural projects across the world and more particularly in Africa and Arab countries. UAE should take advantage of the $\mathrm{B} \& \mathrm{R}$ project to improve its infrastructure and increase exports to China.

\subsection{Recommendations for Further Research}

The findings indicate that the B\&R initiative has had an impact on the trade between China and the UAE. According to the reviewed literature, trade between the two nations targets different sectors, whereby China exports its technological and infrastructural capabilities to the UAE whereas the latter majorly exports crude oil to China. As such, future studies can investigate the impact of the B\&R initiative on specific economic sectors in the two nations.

The study findings indicate that there is a trade imbalance between China and the UAE. As such, future studies can explore the collaborative measures that the two nations can adopt to minimize the imbalance and strengthen the cooperation associated with the B\&R initiative. The findings from such studies would help the two countries to minimize the trade gap.

The impact of $\mathrm{B} \& \mathrm{R}$ initiative cannot be covered fully from an economic perspective. There is need to focus on the social and political impact of the project on the partner countries and how it has shaped the political dynamics of the entire region. The current study only focuses on the economic impact which mainly deals with trade. There are other impacts of the project which include immigration and social integration. Currently, there are over 200000 Chinese citizens in UAE and this could have its own social impact such as setting up Chinese schools and adoption of new cultural practices. An in depth research is required to focus on all these factors and bring a clearer picture of the impact of $B \& R$ project on different dimensions of the UAE society.

\section{References}

[1] Roger, Antonio F.D. China-Portugal relations: Analysis and prospects in the context of the Belt and Road initiative, Master Thesis, University of Lisbon, 2017. 
International Journal of Social Science and Economic Research

ISSN: 2455-8834

Volume:05, Issue:12 "December 2020"

[2] Joshua, Eisenman. Contextualizing China's Belt and Road Initiative. Written Testimony for the USCC. University of Texas, Austin, 2018.

[3] Jonathan, Fulton. China's relations with the Arab Gulf monarchies: Three case studies. Phd Dissertation Leicester: University of Leicester, 2016.

[4] Mo, C. Exploring economic relations between China and the GCC. Journal of Middle Eastern and Islamic Studies (in Asia), 2011, 5(4), 88-105.

[5] Reuters. China total trade to grow 3.5\% in 2015. Khaleej Times, December 28, 2014. Available from https://www.khaleejtimes.com/article/20141228/ARTICLE/312289943/1038

[6] Rakhmat, M.Z. The UAE and China's thriving partnership. The Huffpost. 2018.

[7] Lee, Paul Tae-Woo, Zhi-Hua Hu, Sang-Jeong Lee, Kyoung-Suk Choi, and Sung-Ho Shin. Research trends and agenda on the Belt and Road (B\&R) initiative with a focus on maritime transport. Maritime Policy \& Management (2017): 1-19.

[8] Fan, Zhaobin, Ruohan Zhang, Xiaotong Liu, and Lin Pan. 2016. China's Outward FDI Efficiency Along the Belt and Road.China Agricultural Economic Review 2016, 8 (3): 455-479.

[9] Wang, Guiguo. The Belt and Road Initiative in Quest for a Dispute Resolution Mechanism. Asia Pacific Law Review, 2017, 25 (1): 1-16.

[10] Zhao, Xin, and Murat Karagoz. "Potential of Istanbul as an International Financial Center: A Comparison with Shanghai and Dubai." Procedia economics and finance 38 (2016): 232-244.

[11] Zongyuan, Liu. Rising Chinese Waves in the UAE, 2015. http://www.mei.edu/content/map/rising-chinese-waves-uae\#_ftn2

[12] Fogel, Georgine K. Business environment in China: Economic, Political and Cultural factors. 2010. https://www.usi.edu/media/3654697/Business-Environment-China.pdf

[13] Olimat, Muhamad. China and the Middle East: From Silk Road to Arab Spring. London: Routledge, 2013.

[14] Muhammad Zulfikar Rakhmat. The UAE and China's Thriving Partnership. 2015 https://www.huffingtonpost.com/muhammad-zulfikar-rakhmat/the-uae-and-chinasthrivi_b_7821640.html

[15] Staff writer. UAE-China trade exceeds \$35bn in first nine months of 2017. 2017 
International Journal of Social Science and Economic Research

ISSN: 2455-8834

Volume:05, Issue:12 "December 2020"

http://www.arabianbusiness.com/politics-economics/385749-uae-china-trade-exceeds-35bn-infirst-nine-months-of-2017

[16]. Liao, S., \& McDowell, D. Redback rising: China's bilateral swap agreements and renminbi internationalization. International Studies Quarterly, 2015, 59(3), 401-422.

[17] Sandhya D'Mello.. UAE, China trade to hit \$80b in two years. Khaleej Times. 2018.

[18] Emma Scott.China's “One Belt, One Road” Strategy Meets the UAE's look east policy. China Brief, 2015, 15(11), 1-4

[19]. Staff Report. 12 $2^{\text {th }}$ Chinese Commodities Fair Sharjah opens. Al Nisr Publishing LLC. 2013. 